\title{
PROSPEK DAN STRATEGI BERSAING PADA INDUSTRI SANGKAR BURUNG BERKICAU DI INDONESIA
}

\author{
Wasis Gunadi \\ Dosen Manajemen Unsurya \\ wasisgunadi@yahoo.com
}

\begin{abstract}
Abstrak
Industri sangkar burung berkicau tumbuh dan berkembang sejalan dengan semakin meningkatnya penggemar burung berkicau, baik pengemar rumahan maupun pelomba burung berkicau.

Tulisan ini merupakan kajian pustaka dan menggunakan metoda Analisis Struktur Industri. Partisipan pada Industri Sangkar Burung Berkicau ini sebagian besar adalah Usaha Mikro, Kecil dan Menengah (UMKM) Indonesia yang seluruhnya berjumlah hamper 60 juta orang.

Hasil analisis kekuatan industri ini adalah bahwa hanya ancaman masuknya pendatang baru yang tinggi, sedangkan kekuatan lainnya yaitu ancaman dari produk substitusi, bargaining power of buyer, bargaining power of supplier, serta intensitas persaingan (kecuali pada partisipan berskala usaha menengah), semuanya rendah.

Melihat kondisi kekuatan-kekuatan yang berpengaruh tersebut, maka dimungkinkan penerapan strategi bersaing Cost Leaderships, Product Differentiation, strategi Focus. Strategi kemitraaan antara produsen sangkar berskala kecil/mikro dengan produsen berskala menengah juga berjalan dengan baik dan alamiah.

Key word : Cost Leaderships, Product differentiation dan Focus.
\end{abstract}

\section{PENDAHULUAN}

Memelihara burung berkicau sudah menjadi hobby dan tradisi nenek moyang kita sejak jaman Mojopahit atau bahkan sebelumnya. Burung-burung berkicau yang semula dipelihara karena hobby ini mulai dilombakan sejak tahun 1980 an. Sejak dilombakannya burung berkicau, industriindustri yang terkait dengan dunia perburungan berkicau ini mulai berkembang. Industri-industri tersebut antara lain budidaya dan pelestarian populasi burung berkicau, pakan, vitamin dan obat-obatan burung berkicau, sangkar dan asessories sangkar burung berkicau, serta industri jasa Lomba Burung Berkicau.

Industri sangkar burung berkicau sudah sejak lama tumbuh dan berkembang, yang pada umumnya merupakan indutri kerajinan rumahan yang dikelola oleh Usaha Mikro, Kecil, dan Menengah, yang berjumlah hampir 60 juta orang pelaku usaha.

Saat ini produsen sangkar burung berkicau yang memiliki rentang yang lebih luas mulai dari usaha mikro sampai usaha menengah, makin diminati oleh pelaku usaha menengah. Beberapa partisipan pada industri ini antara lain CV. Ebod Jaya, BnR, Oriq Jaya, Kings, Sangkar Radja, dan ribuan pengrajin sangkar burung berkicau.

Para partisipan (pelaku usaha) pada industri ini mempertahankan dan mengembangkan usaha dengan berbagai strategi yang menurut Porter $(1980 ; 35)$ dapat dikelompokkan menjadi Cost Leaderships, Product differentiation dan Focus. Beberapa 
partisipan mengembangkan usahanya secara individu, beberapa lainnya melalui kemitraan. Pada kemitraan, pelaku usaha yang besar umumnya bertindak sebagai "inti" dari "plasma" yang umumnya terdiri dari pelakupelaku usaha yang lebih kecil. Fenomena ini seperti yang terlihat pada CV Ebod Jaya yang bertindak sebagai inti dari para perajin yang tersebar di semua propinsi di Pulau Jawa (kecuali DKI Jakarta).

Kecenderungan semakin meningkatnya hobby dan lomba burung berkicau di Indonesia, antara lain berdampak pada pertumbuhan industri sangkar burung berkicau. Produk industri ini dapat dikelompokkan menjadi produk sangkar harian dan sangkar untuk lomba, meskipun dalam prakteknya penggunaan sangkar sudah tidak terlalu berbeda antara sangkar harian dan sangkar lomba. Kecenderungan ini meningkat terutama mulai berkurangnya penggunaan sangkar-sangkar mewah dan mahal untuk lomba burung berkicau.

Sudah barang tentu fenomena ini mengharuskan produsen-produsen sangkar untuk memodifikasi strategi bersaing masingmasing. Produsen-produsen sangkar mewahpun dituntut untuk juga memproduksi sangkar standar (biasa).

Strategi-strategi bersaing yang variatif antar partisipan pada industri inilah yang akan dianalisis dan disajikan dalam tulisan ini.

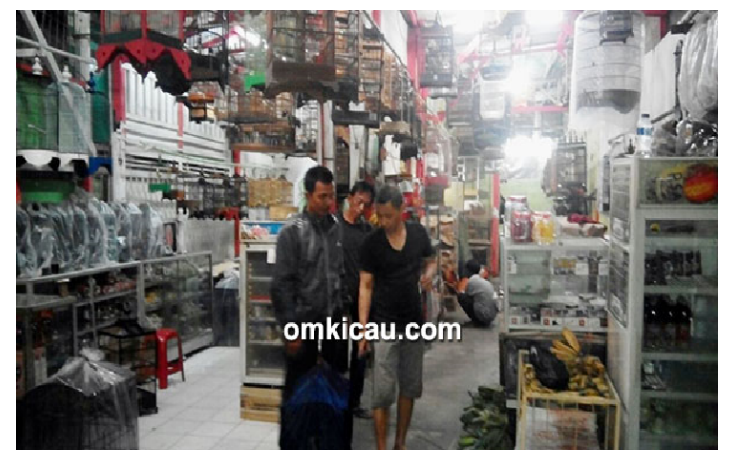

Berbagai Macam Sangkar Burung

\section{TUJUAN}

1. Mengetahui struktur industri sangkar burung berkicau.

2. Melakukan analisis terhadap struktur industri sangkar burung berkicau.

3. Mengetahui prospek industri sangkar burung berkicau.

4. Menyusun strategi bersaing pada industri sangkar burung berkicau.

\section{ANALISIS STRUKTUR INDUSTRI}

Industri sangkar burung berkicau memiliki struktur yang sama dengan industri pada umumnya. Menurut Porter (1980; 4), aturan dan peran persaingan dalam tiap industri dibentuk oleh lima kekuatan persaingan, yaitu industry competitors (seperti CV Ebod Jaya, BnR, Oriq Jaya, sangkar Radja), buyers (pada umumnya adalah penggemar burung berkicau), suppliers, new entrants dan substitutes (seperti disajikan pada diagram di bawah ini). 


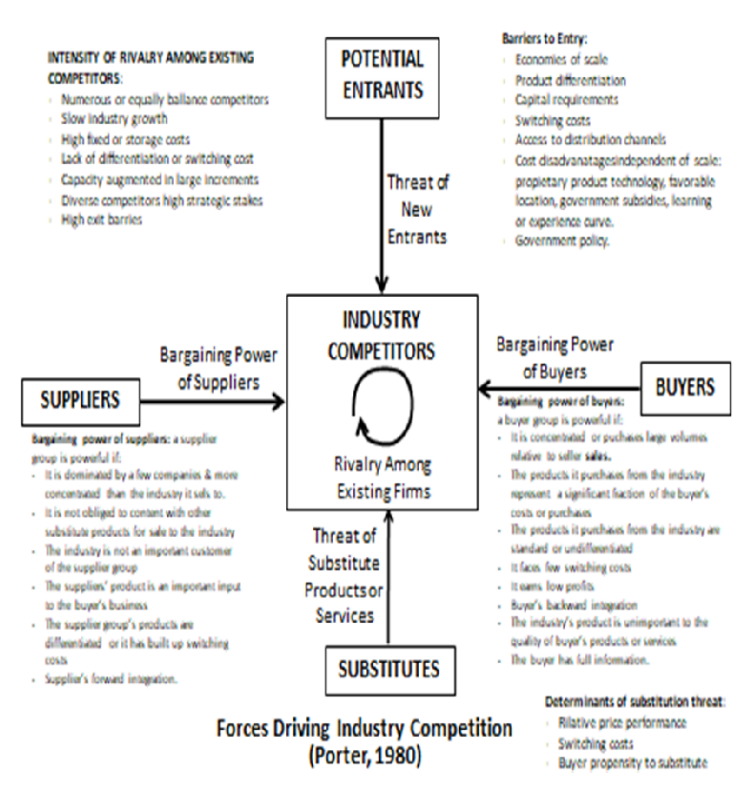

\section{Threat of New Entrants}

New entrants adalah para calon pendatang baru yang akan ikut berpartisipasi dalam industri sangkar burung berkicau. Para calon partisipants ini merupakan ancaman bagi partisipants lama dalam industry. Besar kecilnya ancaman ini tergantung pada halangan untuk masuk ke dalam industri (barriers to entry). Semakin tinggi barriers to entry, maka ancaman masuknya partisipants baru semakin kecil, dan sebaliknya. Determinan yang mempengaruhi tingi/rendahnya barriers to entry ini adalah:

\section{a. Economies of scale}

Economies of scale adalah penurunan biaya per unit akibat meningkatnya volume produksi. Artinya, semakin besar volume produksi (usaha)nya, maka makin rendah biaya produksi per unitnya. Industri sangkar burung berkicau umumnya beroperasi pada ecnomies of scale yang rendah, artinya, industry ini tidak membutuhkan capital yang besar, sehingga relatif mudah dimasuki oleh pendatang baru.

\section{b. $\quad$ Product differentiation}

Product differentiation (perbedaan produk yang dihasilkan industri sangkar burung berkicau) membentuk barriers to entry melalui loyalitas konsumen. Loyalitas konsumen pada industri sangkar burung berkicau relatif rendah (kecuali pada penggemar burung berkicau yang sering mengikuti lomba burung). Pelomba burung cenderung menggunakan sangkar yang memberikan insentif lebih ketika digunakan pada lomba burung tertentu (yang biasanya disponsori oleh produsen sangkar burung berkicau). Namun, secara umum produk standar yang dihasilkan oleh partisipants dan umumnya dikonsumsi oleh konsumen relative sama kualitas dan modelnya, kecuali untuk produk-produk sangkar mewah yang biasanya menonjolkan bahan baku, model dan estetika (biasanya berupa sangkar ukir). Dengan demikian dapat dikatakan bahwa product differentiation yang dihasilkan partisipants relatif tidak menonjol (relatif sama), sehingga lebih memudahkan new entrants memasuki industri sangkar burung berkicau.

\section{c. Capital requirement}

Industri sangkar burung berkicau tidak membutuhkan modal besar, sehingga relatif mudah untuk dimasuki oleh new entrants. Meskipun riset dan pengembangan produk sangkar sangat diperlukan khususnya untuk produk sangkar mewah, namun 
umumnya dilakukan dengan investasi yang relative rendah dan kecil risikonya.

\section{d. Switching cost}

Secara sederhana Switching cost ini dapat diartikan sebagai biaya konsumen untuk pindah membeli ke produsen lain. Oleh karena loyalitas konsumen pada produk tertentu umumnya relative rendah, maka Switching cost pada industri sangkar burung adalah rendah.

Dari beberapa determinan entry barriers tersebut di atas, dapat dikatakan bahwa entry barrier untuk memasuki industri sangkar burung berkicau ini adalah rendah, dengan demikian Threat of new entrants adalah tinggi.

\section{Threat of Substitute Products}

Sangkar burung burung berkicau merupakan salah satu dari sangat sedikit produk yang tidak mempunyai produk pengganti (substitute prodicts). Artinya ancaman yang datang dari produk pengganti pada industri sangkar burung berkicau ini adalah rendah, bahkan tidak ada.

\section{Bargaining Power of buyers}

Pembeli berkompetisi dengan idustri dengan memaksakan harga yang rendah, kualitas produk yang tinggi, dan berpindahpindah dari satu produsen ke produsen lainnya. Tinggi/rendahnya kekuatan pembeli (bargaining power of buyers) ditentukan oleh volume pembelian masing-masing pembeli relative terhadap produksi industri sangkar burung berkicau atau berkelompok/tidaknya pembeli, standar/tidaknya produk, Switching cost, manfaat produk bagi pembeli, integrasi pembeli dengan salah satu produsen, dan informasi tentang produk yang dimiliki oleh produsen.

Pada industri sangkar burung berkicau pembeli tidak berkelompok atau masing-masing membeli produk dalam volume yang relatif sangat kecil terhadap produksi industri, perbedaan kualitas produk umumnya rendah (kecuali untuk produk sangkar mewah) atau dapat dikatakan bahwa produknya standar, Switching cost rendah (kecuali sebagian pelomba yang cenderung loyal pada produsen tertentu), manfaat produk bagi pembeli adalah besar namun tidak dimaksudkan untuk mencari profit, pembeli umumnya tidak memiliki backward integration (berintegrasi dengan produsen tertentu), serta pembeli telah memiliki informasi yang cukup tentang produk. Dengan demikian, dapat dikatakan bahwa kekuatan pembeli adalah rendah.

\section{Bargaining Power of Suppliers}

Grup pemasok (suppliers) memiliki kekuatan yang besar jika: berkelompok, industri bukan konsumen yang penting, produk supplier sangat penting bagi industri, produk supplier berbeda-beda kualitasnyaa atau mampu menciptakan Switching cost, supplier memiliki integrasi dengan pembeli tertentu (forward integration). Supplier pada 
industri sangkar burung berkicau adalah produsen bahan baku sangkar burung (produsen bambu dan kayu bagi perajin sangkar) dan produk sangkar yang masih mentah atau belum di-furnish (bagi produsen besar). Pada produsen sangkar burung berskala usaha menengah umumnya supplier tidak berkelompok, produk supplier sangat penting bagi industri namun memiliki Switching cost yang rendah, sebagian kecil dari suppliers berintegrasi ke depan (forward integration), seperti plasmanya CV Ebod Jaya. Memperhatikan determinan tersebut, maka bisa dikatakan bahwa kekuatan supplier adalah rendah.

\section{Intensity of Rivalry}

Persaingan antar kompetitor pada indstri sangkar burung berkicau terjadi karena salah satu atau lebih kompetitor merasa tertekan atau melihat adanya kesempatan untuk memperbaiki posisinya. Pada kebanyakan industri, perusahaan-perusahaan di dalamnya saling mempengaruhi, sehingga perubahan apapun yang dilakukan salah satu perusahaan akan direspon oleh para kompetitornya. Fenomena tersebut juga terlihat pada indstri sangkar burung berkicau. Jika "aksi-reaksi" tersebut meningkat, maka seluruh perusahaan dalam industri akan merasakan kondisi yang lebih buruk daripada sebelumnya. Intensitas persaingan antar kompetitor dipengaruhi oleh:

a. $\frac{\text { Jumlah dan keseimbangan }}{\underline{\text { kompetitor }}}$

Jika kompetitor makin banyak dan makin seimbang, maka persaingan antar kompetitor semakin intensif dan ketat. Produsen sangkar berskala kecil jumlahnya banyak dan relative seimbang kekuatannya, sedangkan produsen sangkar kelas menengah jumlahnya hanya beberapa dengan kekuatan finansial yang relative beragam, didominasi oleh CV Ebod Jaya.

\section{b. Pertumbuhan Industri.}

Intensitas persaingan meningkat jika pertumbuhan industri menurun, dan sebaliknya. Industri sangkar burung berkicau tumbuh. Baik produsen sangkar skala kecil maupun produsen sangkar skala besar terus meningkat jumlahnya dari waktu ke waktu. Namun karena fenomena ini diikuti dengan meningkatnya jumlah penggemar dan pelomba burung berkicau, hal ini relatif tidak mempengaruhi intensitas persaingan antar produsen sangkar burung berkicau.

\section{c. Switching cost.}

Switching cost pada industri sangkar burung berkicau dapat dikatakan rendah, karena hamper tidak ada pembeli yang loyal, kecuali yang terkait dengan lomba burung berkicau yang disponsori oleh salah satu produsen sangkar.

\section{d. Fixed or Storage Cost.}

Kecuali pada pelaku usaha sangkar berskala menengah, maka biaya tetap dan penyimpanan pada umumnya rendah, karena industri sangkar burung berkicau pada umumnya merupakan industri kerajinan rumahan. 


\section{e. Exit Barriers.}

Industri sangkar burung berkicau mempunyai exit barrier yang rendah, kecuali pada industri sangkar burung berkicau skala menengah. Jadi, kapan saja partisipan dapat dengan mudah keluar dari industri tanpa menanggung kerugian financial yang besar.

Memperhatikan penjelasan-penjelasan tersebut di atas, maka intersitas persaingan antar kompetitor adalah relative rendah pada skala usaha kecil dan relative tinggi pada skala usaha menengah.

\section{PROSPEK INDUSTRI SANGKAR BURUNG BERKICAU}

Jumlah pengemar dan pelomba burung berkicau meningkat dari waktu ke waktu. Indikasinya antara lain bertambahnya jumlah kios-kios penjual burung berkicau, sangkar dan asessoriesnya, serta meningkatnya jumlah pengelola lomba burung berkicau. Dengan demikian permintaan terhadap sangkar burung berkicau juga meningkat dari waktu ke waktu. Permintaan terhadap sangkar burung berkicau utamanya berasal dari arena Lomba Burung Berkicau yang "mewajibkan" peserta lomba menggunakan merk sangkar tertentu. Sudah barang tentu, bagi peserta yang menggunakan sangkar dimaksud, jika burungnya juara, mendapat hadiah yang seringkali fantastis nilainya.

Adalah CV Ebod Jaya yang berinisiatif mewajibkan peserta lomba burung berkicau untuk menggunakan produknya, dengan imbalan hadiah yang besar. Untuk harga tiket lomba Rp. 100.000, Juara I nya diganjar dengan hadiah Rp. 5 juta, merupakan terobosan bisnis yang sangat berani. Beberapa waktu kemudian, perajin sangkar burung berikicau di hampir seluruh propinsi di Pulau Jawa kebanjiran order dari CV Ebod jaya untuk mengirim sangkar burung unfurnished.

"Kemitraan" informal antara CV Ebod Jaya dengan para perajin sangkar burung berkicau makin meningkatkan prospek industri sangkar burung berkicau.

\section{STRATEGI BERSAING PADA INDUSTRI SANGKAR BURUNG BERKICAU}

Analisis industri yang menunjukkan tingginya ancaman masuknya pendatang baru, sangat rendahnya ancaman dari produk substitusi, rendahnya bargaining power of buyer, rendahnya bargaining power of supplier, serta rendahnya intensitas persaingan (kecuali pada partisipan berskala usaha menengah), memungkinkan penerapan strategi bersaing Cost Leaderships, Product Differentiation, dan atau strategi Focus.

Penerapan strategi cost leadership dimungkinkan terutama karena ketersediaan bahan baku dan SDM yang murah. Melimpahnya bahan baku sangkar yang merupakan keunggulan kompetitif Indonesia ini, memungkinkan produsen sangkar burung beroperasi dengan biaya yang rendah, ditunjang oleh melimpahnya SDM. Strategi product differentiation juga mudah diterapkan 
terutama karena SDM kreatif, inovatif dan memiliki kekhasan (terdiri dari berbagai etnis dengan budayanya) juga tersedia melimpah. Adapun strategi focus yang hanya konsentrasi pada pelayanan ceruk pasar tertentu, sudah barang tentu sangat mungkin diterapkan.

Ketiga strategi tersebut lebih tepat ditempuh oleh produsen sangkar berskala usaha kecil, sedangkan untuk produsen sangkar berskala menengah lebih tepat menerapkan strategi product differentiation, terutama karena memiliki merk (yang mampu dipromosikan) dimana umumnya konsumen loyal pada merk tersebut. Dengan demikian, produk bermerk sangkar produsen berskala usaha menengah tersebut masih memiliki daya saing, meskipun harganya lebih mahal (di atas rata-rata harga pasar).

Sejak awal tahun 1990 an produsenprodusen sangkar burung berkicau khususnya yang berskala menengah seperti CV Ebod Jaya dan BnR bekerjasama dengan Event Organizer Lomba Burung Berkicau mewajibkan para peserta lomba burung berkicau untuk menggunakan sangkar produksi dan merk Ebod Jaya atau BnR, dengan kompensasi hadiah kejuaraan yang tinggi nilainya. Strategi ini terbukti efektif untuk mendongkrak permintaan terhadap sangkar merk-merk tersebut yang bahan mentahnya dipasok oleh sebagian besar produsen sangkar berskala kecil. Lambat laun produksi sangkar burung berkicau meningkat, yang diiringi dengan meningkatnya volume usaha produsen sangkar burung berkicau baik yang berskala ekonomi kecil maupun yang menengah.

Yang menarik adalah bahwa antara produsen sangkar skala kecil dan skala menengah secara informal telah melakukan hubungan kemitraan usaha, yang "win-win". Produsen sangkar berskala menengah bertindak sebagai "inti"nya "plasma" yang terdiri dari produsen-produsen berskala kecil.

Dalam lima tahun terakhir, strategi product differentiation yang diterapkan oleh Ebod Jaya dan BnR ini diikuti oleh produsenprodusen lain seperti Oriq Jaya dan Sangkar Radja. Akibatnya, permintaan produk sangkar burung berkicau semakin meningkat.

Strategi product differentiation umumnya ditempuh oleh produsen sangkar berskala menengah karene umumnya mereka mampu melakukan inovasi-inovasi dan update produk terutama desainnya, serta tertutama promosi secara intensif yang dilakukan dengan bekerjasama dengan EO Lomba Burung Berkicau.

\section{KESIMPULAN}

1. Struktur industri sangkar burung berkicau dibentuk oleh lima elemen kekuatan yaitu Threat of new entrants, Threat of substitutes, bargaining power of buyer, bargaining power of supplier, serta intensity rivalry.

2. Hasil analisis struktur industri menunjukkan bahwa pada industri sangkar burung berkicau memiliki Threat of entry yang tinggi, sedangkan Threat of 
substitutes adalah rendah. Bargaining power of supplier dan bargaining power of buyer adalah rendah, intensitas persaingannya juga rendah

3. Industri sangkar burung berkicau mempunyai prospek yang bagus, terutama karena meningkatnya permintaan, melimpahnya bahan baku dan melimpahnya SDM kreatif dan inovatif yang mampu menghasilkan produk yang tampil beda.

4. Ketiga strategi bersaing yaitu Cost Leaderships, product differentiation. dan focus dapat diterapkan pada industri sangkar burung berkicau pada produsen berskala ekonomi mikro dan kecil, sedangkan yang berskala ekonomi menengah sebaiknya menerapkan strategi product differentiation.

\section{DAFTAR PUSTAKA}

Carlin International. 2012. Design Prediction. Unpublished.

Kotler, Philip and Keller, Kevin Lane. 2012. Marketing Management. Pearson Education, Inc publishing as Prentice Hall, One Lake Street, Upper Saddle River, New Jersey 07458.

Laporan Tahunan Kementerian KUKM RI tahun 2016. 2017. Kementerian KUKM RI.

Porter, Michael E. 1980. Competitive Strategy. The Free Press, a Division of Macmillan, Inc. 866 Third Avenue, New York, NY 10022.

1985. Competitive Advantage. The Free Press, a Division of
Macmillan, Inc. 866 Third Avenue, New York, NY 10022.

1990. Competitive Advantage of Nations. The Free Press, a Division of Simon \& Schuster Inc. 1230 Avenue of the Americas, New York, NY 10020. 